\title{
CAMPUR KODE DAN ALIH KODE MASYARAKAT PESISIR PANTAI LIPPO LABUAN (KAJIAN SOSIOLINGUISTIK)
}

\author{
Yayah Juariah $^{1}$, Astini Uyun ${ }^{2}$, Ojah Sri Nurhasanah ${ }^{3}$, Ilas Sulastri ${ }^{4}$ \\ Universitas Sultan Ageng Tirtayasa \\ lyayahe65@gmail.com, 2astiniuyun@gmail.com, 30jahsrinurhasanah401@gmai.com, \\ ${ }^{4}$ ilassulastri83@gmail.com
}

\begin{abstract}
Abstrak
Penelitian ini bertujuan untuk mengetahui bahasa sehari-hari yang digunakan masyarakat pesisir Pantai Lippo Labuan dalam berinteraksi, baik dengan sesama penduduk setempat maupun pendatang. Berdasarkan hasil observasi diketahui bahwa dalam proses percakapan masyarakat pesisir Pantai Lippo Labuan sering menggunakan campur kode dan alih kode bahasa (Sunda-Jawa) sangat menarik untuk diteliti sehingga dapat memberikan gambaran penggunaan campur kode dan alih kode yang dilakukan masyarakat pesisir Pantai Lippo Labuan. Jenis penelitian ini adalah penelitian kualitatif. Data penelitian adalah bahasa yang digunakan masyarakat pesisir Pantai Lippo Labuan. Dalam penelitian kualitatif yang menjadi instrumen atau alat penelitian adalah peneliti itu sendiri. Teknik pengumpulan data dalam penelitian ini meliputi observasi (simak), rekam, dan catat. Pengumpulan data dilanjutkan dengan penganalisisan wujud, jenis, dan faktor penyebab campur kode dan alih kode masyarakat pesisir Pantai Lippo Labuan. Campur kode dan alih kode yang dilakukan masyarakat pesisir Pantai Lippo Labuan memiliki alasan yang jelas.
\end{abstract}

Kata Kunci: campur kode, alih kode, wujud, jenis dan faktor penyebab

\begin{abstract}
This study aims to determine the daily language used by the Lippo Labuan coastal community in interacting with fellow locals and migrants. Based on observations it is known that in the process of conversation the people of the Lippo Labuan coast often use mixed codes and language code switching (Sundanese, Javanese) very interesting to study, so that they can give an overview of the use of mixed codes and code switching by the Lippo Labuan coastal community. This type of research is qualitative research. The research data is the language used by the Lippo Labuan coastal community. In qualitative research, the researcher becomes the instrument or research tool. Data collection techniques in this study include observation (see), record and record. Data collection was followed by analyzing the forms, types and factors causing code mixing and code switching of the Lippo Labuan coastal community. The code mixing and code switching carried out by the Lippo Labuan coastal community has clear reasons).
\end{abstract}

Keywords: code mix, code switch, form, type and causes

\section{PENDAHULUAN}

Bahasa merupakan alat komunikasi yang berupa sistem bunyi, komunikasi mempunyai definisi berupa suatu sistem yang dimiliki manusia dalam kegiatan seharihari, meskipun dalam kegiatan komunikasi sebagian besar masyarakat menggunakan 
bahasa nasional, tetapi dalam komunikasi antarsuku bahasa daerah memiliki peranan yang sangat penting dalam komunikasi antar masyarakat. Masyarakat yang menggunakan dua bahasa atau lebih dalam berbicara disebut bilingual dan multilingual atau dwibahasawan.

Menurut Mackey dalam Chaer (2010:84), secara sosiolinguistik dwibahasa diartikan sebagai penggunaan dua bahasa oleh seorang penutur dengan pergaulannya dengan orang lain secara bergantian, selain bahasa ibu sebagai bahasa pertama penutur juga menguasai bahasa kedua yaitu bahasa lain yang menjadi bahasa keduanya, orang yang kedua menggunakan bahasa tersebut disebut dwibahasa. Seseorang dapat menjadi dwibahasawan pada waktu anak-anak dan pada waktu dewasa, sedangkan peristiwa tersebut dapat terjadi dilingkungan sekolah, lingkungan keluarga, bahkan lingkungan masyarakat.

Adanya bilingualisme atau multilingualisme inilah yang menyebabkan masyarakat menggunakan pengalihan dan pencampuran bahasa dalam berbicara. Pengalihan atau pencampuran bahasa pertama ataupun bahasa kedua sehingga munculah tentang campur kode dan alih kode dalam berbicara.

Campur kode adalah peristiwa pencampuran bahasa yang satu dengan bahasa yang lain. Chaer dan Agustina (2010:114) menjelaskan bahwa campur kode adalah pemakaian dua bahasa atau lebih atau dua varian dari sebuah bahasa dalam suatu masyarakat tutur, terdapat kode utama atau kode dasar yang digunakan yang memiliki fungsi keotonomiannya, sedangkan kode-kode lain yang terlibat dalam peristiwa tutur itu hanyalah berupa serpihan saja.

Kridalaksana (dalam Suandi, 2014:139) berpendapat bahwa campur kode adalah interferensi penggunaan satuan lingual bahasa dari satu bahasa ke bahasa lain untuk memperluas gaya bahasa atau ragam bahasa; termasuk di dalamnya pemakaian kata, klausa, idiom, sapaan, dan sebagainya. Suatu contoh, ketika mengacu pada pencampuran (mixing) dalam komunikasi yang dikembangkan oleh seorang penutur bilingual atau multilingual, ia melibatkan penggunaan unsur-unsur bahasa $X$ dalam suatu ujaran bahasa Y, maka akan terjadi peristiwa campur kode. Unsur-unsur itu bisa bersifat leksikal, sintaksis, atau semantik. Berbicara tentang konsep campur kode, akan dekat relasinya dengan konsep interferensi, yakni penyimpangan dari norma dalam setiap bahasa yang disebabkan oleh kedekatan antara dua bahasa. Namun, pencampuran (mixing) itu sama sekali bukan merupakan peristiwa interferensi, tetapi merupakan ungkapan strategi yang spesifik bagi penutur bilingual.

Menurut (Susmita, 2015: 98) alih kode merupakan suatu fenomena kebahasaan yang bersifat sosiolinguistik dan merupakan gejala yang umum dalam masyarakat dwibahasa atau multibahasa, sedangkan Ohoiwutun (dalam Susmita, 2015: 98) menyatakan bahwa alih kode pada hakikatnya merupakan pergantian pemakaian bahasa atau dialek.

Campur kode dibagi menjadi tiga, yaitu campur kode ke dalam, campur kode ke luar, dan campur kode campuran. Menurut Suandi (2014:140-141), campur kode ke dalam (inner code mixing) adalah jenis campur kode yang menyerap unsur-unsur bahasa ali yang masih sekerabat, misalnya dalam peristiwa campur kode pada tuturan bahsa Indonesia terdapat di dalamnya unsur-unsur bahasa daerah. Campur kode ke luar (outer code mixing) adalah campur kode yang menyerap unsur-unsur bahasa asing, misalnya gejala campur kode pada pemakaian bahasa Indonesia terhadap sisipan bahasa asing. Campur kode campuran (hybrid code mixing) adalah campur kode yang di dalamnya 
mungkin klausa atau kalimat telah menyerap unsur bahasa asli (bahasa-bahasa daerah) dan bahasa asing.

Alih kode dibedakan menjadi dua jenis yaitu alih kode ke dalam/ intern dan alih kode ke luar/ ekstern. Menurut Jendra (dalam Padmadewi dkk., 2014:65), alih kode ke dalam adalah alih kode yang terjadi bila si pembicara dalam pergantian bahasanya menggunakan bahasa-bahasa yang masih dalam ruang lingkup bahasa nasional, sedangkan alih kode luar adalah alih kode yang dalam pergantian bahasanya si pembicara mengubah bahasanya dari bahasa satu ke bahasa lain atau ke bahasa asing.

Hal ini sejalan dengan pendapat Kunjana (2010:20) beliau juga menyebut apa yang disebut alih kode intern (internal code switching), yakni yang terjadi antarbahasa daerah dalam suatu bahasa nasional, antardialek dalam satu bahasa daerah, atau antara beberapa ragam dan gaya yang terdapat dalam suatu dialek. Adapun yang dimaksud dengan alih kode ekstern (external code switching) adalah peralihan bahasa yang terjadi antara bahasa dasar (base language) dengan bahasa asing.

Ketika seseorang berkomunikasi menggunakan campur kode dan alih kode maka dipengaruhi oleh beberapa faktor diantaranya, faktor latar belakang dan sikap, latar belakang bahasa, mitra bicara keterbatasan penggunaan kode, hadirnya penutur ketiga dan masih banyak lagi.

Teori menyediakan berbagai argumentasi yang dapat digunakan untuk menganalisis atau memberikan penafsiran atas hasil penelitian yang telah diolah. Oleh sebab itu, berikut akan dijabarkan beberapa teori yang akan digunakan dalam penelitian ini.

Sosiolinguistik, menurut Downes dalam Rosidin (2014: 177) mengemukakan bahwa sosiolinguistik adalah cabang linguistik yang mengkaji hanya bagian bahasa yang penjelasannya memerlukan acuan faktor-faktor sosial, termasuk faktor kontekstual. Menurut Yulianto dkk. (2019: 99) Sosiolinguistik adalah cabang ilmu yang bersifat interdisipliner dengan ilmu sosiologi, dengan objek penelitian hubungan bahasa dengan faktor-faktor sosial di dalam suatu masyarakat tutur.

Campur Kode, menurut Nursaid dan Maksan (2002:114) bahwa campur kode merupakan pergantian dua bahasa atau lebih, dua ragam atau lebih, dua dialek atau lebih yang terjadi bukan dikarnakan faktor situasi dan keperluan, melainkan oleh beberapa faktor untuk menaiki kedudukan atau drajat si penutur. Campur kode adalah peristiwa pencampuran bahasa yang satu dengan bahasa yang lain. Rokhman, (2011:39) menjelaskan bahwa campur kode adalah pemakaian dua bahasa atau lebih dengan saling memasukkan unsur bahasa yang satu ke dalam bahasa yang lain. Sejalan dengan pendapat tersebut Sumarsono dalam Riansi (2017:176) menyatakan bahwa campur kode terjadi apabila penutur menyelipkan unsur-unsur bahasa lain ketika sedang memakai bahasa tertentu.

Berdasarkan unsur-unsur kebahasaan yang terlibat di dalamnya, menurut Chaer (2010: 115) campur kode dapat dibedakan menjadi beberapa macam yaitu: (1) kata dasar; (2) frase; dan (3) klausa.

Campur kode dibedakan menjadi tiga jenis, yaitu alih kode ke dalam (inner code mixing), campur kode ke luar (outer code mixing), dan campur kode campuran (hybrid code mixing). Menurut Suandi (2014:140-141), campur kode ke dalam (inner code mixing) adalah jenis campur kode yang menyerap unsur-unsur bahasa asli yang masih sekerabat. Campur kode ke luar (outer code mixing) adalah campur kode yang menyerap unsur-unsur bahasa asing. Campur kode campuran (hybrid code mixing) adalah campur 
kode yang di dalamnya (mungkin klausa atau kalimat) telah menyerap unsur bahasa asli (bahasa-bahasa daerah) dan bahasa asing.

Faktor terjadinya campur kode bermacam-macam mulai dari keterbatasan kata dalam bahasa Indonesia sehingga penutur menggunakan sisipan bahasa lain sebagai pengganti. Terdapat dua faktor penyebab terjadinya campur kode menurut Suwito (dalam Suandi, 2014:142) yakni, latar belakang sikap penutur dan latar belakang kebahasaan.

Alih kode, Rokhman (2011) menyatakan bahwa alih kode merupakan peralihan dari kode satu ke kode yang lain karena perubahan situasi yang mungkin terjadi antar bahasa, antarvarian (baik regional maupun sosial) antarregister, antarragam, ataupun antargaya.

Alih kode mempunyai beberapa bentuk, menurut Soewito (dalam Chaer dan Agustina, 2010:114) membedakan alih kode menjadi dua macam, yaitu alih kode intern dan alih kode ekstern. Alih kode intern adalah alih kode peralihan dari bahasa penutur kebahasa yang serumpun, seperti bahasa Indonesia ke bahasa Jawa, atau sebaliknya. Alih kode ekstern alih kode yang terjadi antara bahasa penutur dengan bahasa asing atau bahasa yang tidak serumpun, seperti dari bahasa Indonesia ke bahasa Inggris atau sebaliknya.

Faktor-faktor penyebab terjadinya alih kode, Aslinda dan Leni Syafyahya (2014:85) menyebutkan di antaranya: (1) siapa yang berbicara; (2) dengan bahasa apa; (3) kepada siapa; (4) kapan; dan (5) dengan tujuan apa. Dalam berbagai kepustakan linguistik, secara umum penyebab terjadinya alih kode antara lain: (1) pembicara/penutur; (2) pendengar/lawan tutur; (3) perubahan situasi dengan hadirnya orang ke tiga; (4) perubahan dari formal ke informal/sebaliknya; dan (5) perubahan topik pembicaraan.

\section{METODE PENELITIAN}

Dalam melakukan penelitian campur kode dan alih kode ini peneliti menggunakan pendekatan kualitatif. Pendekatan kualitatif adalah pendekatan yang penting untuk memahami suatu fenomena sosial dan perspektif individu yang diteliti. Tujuannya adalah menggambarkan, mempelajari, dan menjelaskan fenomena itu (Syamsyudin dan Damaianti, 2011: 74).

Metode yang digunakan adalah deskriptif. Metode deskriptif dinilai dapat mendeskripsikan bentuk, faktor, campur kode dan alih kode masyarakat pesisir Pantai Lippo Labuan. Sumber data dalam penelitian ini adalah percakapan oleh masyarakat pesisir Pantai Lippo Labuan yang menggunakan campur kode dan alih kode.

Data primer dalam penelitian ini berupa percakapan yang mengandung campur kode dan alih kode masyarakat pesisir Pantai Lippo Labuan. Sementara itu data skunder dalam penelitian ini adalah berupa informasi dari hasil diwawancara dengan teknik cakap bertemu muka.

Teknik pengumpulan data dalam penelitian ini meliputi observasi (simak), teknik rekam dan catat. Pengumpulan data dengan observasi adalah pengamatan dan pencatatan secara sistematis terhadap gejala yang tampak pada objek penelitian. Penelitian menggunakan pengamatan dan pencatataan yang dilakukan terhadap objek sehingga observer bersama objek yang diteliti.

Dalam analisis data, data yang telah terkumpul diidentifikasi dan diklarifikasi. Menurut Moleong (2012-280) langkah-langkah atau proses analisis data secara umum dapat digunakan dengan menelaah seluruh data yang tersedia dari beberapa sumber, kemudian menyusun dalam satuan-satuan, lalu dikatagorikan dan pemeriksaan keabsahan 
data setelah selesai semua tahapan ini, mulailah tahapan penafsiran data untuk mengolah hasil sementara menjadi teori substansif dengan menggunakan metode tertentu.

Berdasarkan pendapat Moelong di atas dapat dispesifikasikan langkah-langkah yang digunakan dalam penelitian, yakni di mulai dengan mengidentifikasi, mendeskripsikan perilaku campur kode dan alih kode, disimpulkan, dan penyajian hasil analisi.

Menurut Mahsun (2005:116), hasil analisis berupa kaidah-kaidah dapat disajikan melalui dua cara, yaitu (1) perumusan dengan menggunakan kata-kata bisa yang bersifat teknis dan (2) perumusan dengan menggunakan tanda-tanda atau lambang-lambang. Kedua cara tersebut masing-masing disebut metode informal dan metode formal. Sejalan dengan pernyataan tersebut, dalam penelitian ini, metode yang dipakai untuk menyajikan hasil analisis data adalah metode penyajian informal. Menurut Sudaryanto (2015:241), metode penyajian informal adalah perumusan dengan kata-kata biasa.

\section{HASIL DAN PEMBAHASAN}

Tahapan penyampaian data dilakukan dengan tiga tahap, (1) menjelaskan dan mendeskripsikan wujud alih kode dan campur kode, (2) menjelaskan dan menyebutkan jenis alih kode dan campur kode, (3) menjelaskan dan mendeskripsikan faktor yang menyebabkan terjadinya alih kode dan campur masyarakat pesisir Pantai Lippo Labuan.

\section{Campur Kode}

Data 1.1

Samiah : "Urut... urut... urut." (Pijit... pijit... pijit...)

Mia : "Sabaraha bu? Rp. 20.000?" (Berapa bu? Rp.20.000?”

Samiah : "Teu kenging Neng, Biasana mah Rp. 100.000 teu nanaon Rp. 50.000 bae." (Gak bisa neng, biasanya mah Rp. 100.000 gpp Rp. 50.000 aja)

Mia : "Nya atuh bu arek." (Iya bu mau)

Samiah : "Neng anu ti mana kitu?" (Neng dari mana?)

Mia : "Abdi anu ti Pandeglang, bu." (Saya dari Pandeglang, bu)

Samiah : "Ibu geh punya sodara nu ti Pandeglang ayeuna di Rangkas damelna." (Ibu juga punya saudara di Pandeglang sekarang di Rangkas kerjanya)

Mia : "Nya bu. ari ibu asli dieu sanes?" (Ya bu. Kalau ibu asli sini bukan?)

Samiah : "Lain, aslina ibu ti Serang. Nikah sareng orang dieu, cicing di dieu nepi ayeuna." (Bukan, asli ibu dari Serang. Nikah dengan orang sini, tinggal di sini sampai sekaramg)

Mia : "Ibu ngurut tos lila?" (Ibu mijit udah lama?"

Samiah : "Tos 5 tahun. Tadina mah icalan lauk." (Udah 5 tahun. Tadinya mah jualan ikan)

Mia : "Lauk naon bae bu?" (Ikan apa aja bu?)"

Samiah : "Lauk Banyar, Tetedeng, Bentong, Layur, Jambrong, Jojolod, Utik." (Ikan Banyar, Tetedeng, Bentong, Layur, Jambrong, Jojolod, Utik)

Mia : “Ayeuna kenapa ibu teu jualan ikan?” (Sekarang kenapa ibu gak jualan ikan?"

Samiah : "Ayeuna mah harese nyiar laukna." (Sekarang mah susah cari ikannya."

Data 1.1 dalam percakapan di atas dilakukan oleh Ibu Samiah dan Mia adalah campur kode ke dalam yang berupa alih kode jenis kata. Campur kode yang digunakan oleh Ibu Samiah adalah campur kode ke dalam yaitu kata due 'punya' dalam bahasa Jawa yang bercampur ke dalam bahasa Sunda. Hal ini dilakukan oleh Ibu Samiah karena faktor 
asal yaitu Serang yang mayoritas menggunakan bahasa Jawa meskipun sudah lama tinggal di Labuan, tetapi bahasa asal masih digunakan walau hanya beberapa kata saja. Campur kode selanjutnya dilakukan oleh Mia yang menyisipkan bahasa Indonesia dalam percakapan bahasa Sunda. Hal ini dilakukan karena usia Mia yang masih remaja dan mayoritas penutur remaja seusianya menggunakan bahasa Indonesia dalam bertutur.

Data 1.2

Ibu Laila : "Kemarin mah saya lihat dia jualan di sini."

Pak Ade : "Ya, biasanya dia ada di sini. Soalnya bakso dia itu paling enak di sini."

Ibu Laila : "Ya emang."

Pak Ade : "Kalau ada nomor HP pasti saya telpon."

Ibu Laila : "Coba aja pak tunggu sampai siang. Mudah-mudahan datang."

Data 1.2 dalam percakapan di atas yang dilakukan oleh Ibu Laila dan Pak Ade adalah campur kode ke dalam. Campur kode yang digunakan oleh Ibu Samiah adalah campur kode ke dalam yaitu kata mah adalah ciri khas dari bahasa Sunda yang diselipkan ke dalam bahasa Indonesia. Hal ini dilakukan oleh Bu Laila karena faktor asal, yaitu asli Labuan yang mayoritas menggunakan bahasa Sunda meskipun dalam percakapan menggunakan bahasa Indonesia tetap saja bahasa Sunda sebagai dialek tidak bisa terlepaskan.

\section{Alih Kode}

Data 1.3

Jatiah : "Pisang... pisang... pisang murah."

Waskati : "Sabaraha eta teh?" (Berapa itu teh?)

Jatiah : :Rp. 50.000 bae satundunna." (Rp.50.000 setandan)

Waskati : "Rp. 40.000 bae nya teh. Abdi arek yeuh satundun." (Rp. 40.000 aja teh. Saya mau nih satu tandan)

Jatiah : : "Nya atuh mangga." (Ya silakan)

Data 1.3 dalam percakapan di atas yang dilakukan oleh Ibu Jatiah dan Ibu Waskati adalah alih kode ke dalam dan jenis alih kode kalimat. Alih kode ini dilakukan karena Ibu Waskati dan Ibu Jatiah melakukan percakapan dengan menyelipkan bahasa Sunda ke dalam bahasa Indonesia. Alih kode ke dalam bahasa Sunda yang dilakukan keduanya berjalan lancar karena dua-duanya mengerti bahasa Sunda sekaligus untuk menunjukkan keakraban dalam bertransaksi.

Data 1.4

Eli : "Dari mana?"

Jeje : "Dari Binuangen Lebak, pak."

Eli : :Tos lila icalan di dieu?" (udah lama jualan di sini?)

Jeje : "Tos sataun leuwih." (udah setahun lebih)

Eli : "Tiasa nyarios Sunda?" (bisa ngomong bahasa Sunda?)

Jeje : "Tiasa pak, ja basa Sunda bae.” (Bisa pak, biasanya Sunda aja)

Eli : "Nya atuh, ke mun ameng we ke gubug ieu nyah.! (Ya, Nanti kalau main ke gubuk ini ya)

Jeje $\quad$ : "Nya nuhun, pak." (iya makasih, pak) 
Data 1.4 dalam percakapan di atas yang dilakukan oleh Pak Eli dan Jeje adalah alih kode ke dalam dan jenis alih kode kalimat. Alih kode yang dilakukan dari bahasa Indonesia ke bahasa Sunda. Pak Eli mengetahui bahwa Jeje berasal dari Binuangen, bahasa orang Binuangen menggunakan bahasa Sunda. Oleh karena itu, Pak Eli menggunakan bahasa Sunda dalam melanjutkan percakapannya untuk memastikan apakah Jeje bisa bahasa Sunda.

Data 1.5

Ibu Yayah : "Pak beli kelapa."

Pak Sarman: "Nya anu mana Bu?" (Iya yang mana bu?)

Ibu Yayah : "Emang naon bedana pak? Nu ieu jeung anu eta?" (Emang apa bedanya pak? Yang ini sama yang itu?)

Pak Sarman: "Ari anu ieu mah amis caina, seueur daging buahna. Ari anu itu mah teu aya dagingan ngan saukur cai hungkul." (Kalau yang ini manis airnya, banyak daging buahnya. Kalau yang itu mah gak ada dagingnya Cuma ada airnya saja)

Ibu Yayah : "Nya atuh pak, abdi bade anu seueur dagingna." (Ya pak, saya mau yang banyak dagingnya)

Pak Sarman: "Nya, mangga calik bu." (Iya, silakan duduk bu)

Ibu Yayah : "Pak ai bapak usiana sabaraha?" (Pak kalua bapak usianya berapa?)

Pak Sarman: "Abdi mah 84 tahun." (Saya 84 tahun)

Ibu Yayah : "Maenya pak? Masih jagjag tapina. Naon rahasiana pak?" (Masa pak? Tapinya masih kuat. Apa rahasianya pak?)

Pak Sarman: "Rahasiana senangkeun bae hate. Tong mikiran anu teu kudu dipikiran." (Rahasinya bahagiakan hati. Jangan memikirkan apa yanh tidak perlu dipikirkan)

Ibu Yayah : "Pak, ari di dieu mun muriang berobatna ka mana?" (Pak, kalua di sini sakit berobatnya ke mana?)

Pak Sarman: "Ka dokter. Tapina pami abdi mah make obat dadaunan hungkul." (Ke dokter. Tapinya kalua saya pakai obat daun-daunan saja)

Ibu Yayah : "Obat naon tah pak?" (Obat apa itu pak?)

Pak Sarman: "Mun nyeri huntu obatna geutah cau ambon dicocokeun kana huntu anu nyeuri. Mun rematik make jahe jeung pedes ditutuan terus dibalurken. Tapina mun nyeuri sirah mah ku obat Paramek bae." (Kalau sakit gigi obatnya getah pisang Ambon dicocokin ke gigi yang sakit. Kalau rematik pake jahe dan lada ditumbuk lalu diusapkan Tapinya kalua sakit kepala harus sama obat Paramek saja)

Ibu Yayah : "Nya atuh pak eta mah masih dedaunan nu aya di dieu. Teras bapak sok nyeri huntu teu?" (Iya pak itu masih dengan daun-daunan/ tradisonal yang ada di sini. Lalu bapak suka sakit gigi gak?)

Pak Sarman: "Tara nyeuri huntu abdi mah saumur-umur. Sakalina karasa, obatna nganggo geutah bonggol cau, pucukna" (Tidak pernah sakit gigi saya mah seumur-umur. Pernah sekali sakit obatnya pake getah bonggol pisang kuncupnya)

Ibu Yayah : "Hatur nuhun nya Pak, tos kersa ngobrol” (Terima kasih pak, sudah bersedia ngobrol)

Pak Sarman: "Muhun, Bu, ati-ati, sing salamet" (Iya bu hati-hati) 
Data 1.5 dalam percakapan di atas yang dilakukan oleh Pak Sarman dan Bu Yayah adalah alih kode ke dalam dan jenis alih kode kalimat. Alih kode yang dilakukan dari bahasa Indonesia ke bahasa Sunda. Pak Sarman mengetahui bahwa bu Yayah dari logat berbicaranya asli Sunda Parahyangan. Oleh karena itu, Pak Sarman menggunakan bahasa Sunda dalam melanjutkan percakapannya dan tanpa disadari Bu Yayah beralih bahasa dari bahasa Indonesia ke bahasa Sunda untuk memberikan kenyamanan dalam percakapan tersebut.

\section{SIMPULAN}

Sejalan dengan rumusan masalah dan tujuan penelitian yang telah dijelaskan pada bagian pendahuluan, dapat dikemukakan simpulan sebagai berikut: (1) bentuk campur kode dan alih kode dalam percakapan masyarakat pesisir Pantai Lippo Labuan adalah campur kode dan alih kode yang berupa kata dan kalimat; (2) jenis campur kode dan alih kode ke dalam, alih kode dan campur kode ini terjadi dari bahasa Indonesia ke bahasa Sunda, bahasa Jawa, ataupun sebaliknya; (3) faktor penyebab terjadinya campur kode dan alih adalah: (a) faktor penyebab terjadinya campur kode dan alih kode karena penutur, lawan tutur, dan kebiasaan.

\section{DAFTAR PUSTAKA}

Riansi, E. S. (2017). Gejala campur kode pada pengunjung Taman Mini Indonesia Indah. Jurnal Membaca Bahasa dan Sastra Indonesia, 2(2), 175-180.

Susmita, N. (2015). Alih kode dan campur kode dalam pembelajaran bahasa Indonesia di SMP Negeri 12 Kerinci. Jurnal Penelitian Universitas Jambi: Seri Humaniora, 17(2), 87-98.

Yulianto, E., Hilaliyah, H., \& Chadis, C. (2019). Penggunaan bahasa pada transaksi jual beli di toko dalam jaringan (Daring) (Kajian sosiolinguistik). Deiksis: Jurnal Pendidikan Bahasa dan Sastra Indonesia, 6(1), 99-109.

Aslinda, \& Syafyahya, L. (2014). Pengantar sosiolinguistik. Bandung: Refika Aditama.

Chaer, A. (2010). Sosiolinguistik (Perkenalan). Jakarta: PT Rineka Cipta.

Kunjana, R. (2010). Kajian sosiolinguistik. Bogor: Ghalia Indonesia.

Mahsun. (2005). Metode penelitian bahasa: Tahapan, strategi, metode dan tekniknya. Jakarta: PT Raya Gravindo.

Moleong, L. J. (2012). Metodologi penelitian kualitatif. Bandung: Remaja Rosdakarya.

Nursaid, \& Maksan, M. (2002). Sosiolinguistik. Buku Ajar. FBSS: UNP Press.

Padmadewi, N. N., Merlyana, P. D., \& Saputra, N. P. H. (2014). Sosiolinguistik. Yogyakarta: Graha Ilmu.

Rokhman, F. (2011). Sosiolinguistik. Yogyakarta: Graha Ilmu. 
Rosidin, O. (2014). Percikan linguistik. Serang: Untirta Press.

Suandi, I. N. (2014). Sosiolinguistik. Yogyakarta: Graha Ilmu.

Sudaryanto. (2015). Metode dan aneka teknik analisis bahas: Pengantar penelitian wahana kebudayaan secara linguistik. Yogyakarta: Gadjah Mada University Press. 